\title{
昭和58年における「重要な燃料関倸事項」（I ）
}

\author{
(Annual Fuel Reviews - 1983 )
}

\section{目次}

(社)燃料協会編集

随想（セレンディピィティーと

$$
\text { カタストロフィーと天才ー創造への道一) 乾智 行…(439) }
$$

1. 燃料一般

1.1 エネルギー需給の動向…………早本エネルギー経済研究所 高 垣 節 夫…(440)

1.2 工業用然料の動向

1.2.1 電力用燃料……………………………電気事業連合会 石 黑 賢 三 …(444)

1.2.2 製鉄用燃料………………………………本鉄鋼連盟 竹 下 栜 $三 \cdots(446)$

1.2.3 内燃機燃料…………………………………本石油秼 野 村 宏 次…(450)

2. 石炭

2.1 石炭に関する研究

2.1.1 石炭の構造と性質………………九州工業技術試験所 有 田 静 児…(457)

2.1.2 石炭の液化………………北海道工業開発試験所 前河涌典・吉田諒一…(463)

2.1.3 石炭のガス化…………………………東京農工大学 平 戸 瑞 穂…(472)

2.2 石炭鉱業の動向…………………………通産省生活産業局 松 下 哲 也…(477)

2.3 採炭技術の動向（研究を含む）………(財)石炭技術研究所 山 村 禮次郎…(480)

2.4 コークス

2.4.1 コークス工業の動向………………………日本鋼管侏) 島 田 源 嗣…(487)

2.4.2 コークスに関する研究…………………新日鐵化学秼 美 浦 義 明…(508)

2.5 タール

2.5.1 芳香族, タール工業の動向…………本芳香族工業会 渡 辺 義 則…(514)

2.6 石炭灰の有効利用技術の動向（性状を含む）

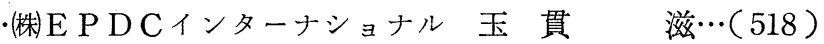

2.7 炭素工業の動向（研究を含む）……………日本カーボン陎 寺 西 春 夫…(521)

3. 石 油

3.1 石油飞関する研究（性状, 構造, 化学) ………本石油秼 山 崎 由 獚…(525)

3.2 石油釷業の動向………………………………石油鉱業連盟 松 本 義 夫…(529)

3.3 石油精製工業の動向……………………………石油連盟 藤 沼 茂…(535)

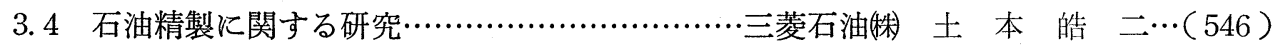

3.5 石油化学

3.5.1 石油化学工業の動向………………………………平 川 芳 彦…(550)

3.5.2 石油化学化関する研究……………公害資源研究所

横山伸也・水野光一・小木知子・㪯藤昌弘・高橋忠雄 $\cdots(556)$

3.6 潤滑油の動向（研究を含む）…………………菱石油秼）星 野 道 男…(571)

4. オイルサンドおよびオイルシェール

4.1 オイルサンドの開発と研究の動向…………公害資源研究所 請 川 孝 治…(573)

4.2 オイルシェールの開発と研究の動向………公害資源研究所 佐 藤 信 也…(575)

5. ガ ス

5.1 天然ガス開発の動向……………………….然ガス鉱業会 小野寺＼cjkstart博…(579)

5.2 都市ガス需給と原料の動向…………………日本ガス協会 大 野 豊…(590)

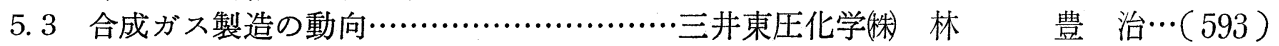

5.4 液化石油ガスの動向………………………讲液化ガス俶) 川 岸 弘…(598)

5.5 ガス化に関する研究……………………早稲田大学理工学部関場徹…(600) 